\title{
Atypical Small Acinar Proliferation of the Prostate Gland
}

National Cancer Institute

\section{Source}

National Cancer Institute. Atypical Small Acinar Proliferation of the Prostate Gland. NCI

Thesaurus. Code C37268.

Focal proliferation of small acinar glandular cells in the prostate gland with cytologic

changes ranging from atypia to highly suggestive of malignancy. 